\title{
Predictive Value of Brain-Specific Proteins in Serum for Neurodevelopmental Outcome after Birth Asphyxia
}

\author{
NICOLE NAGDYMAN, INGRID GRIMMER, TRISTESS SCHOLZ, CHRISTIAN MÜLLER, AND \\ MICHAEL OBLADEN \\ Department of Neonatology [N.N., I.G., T.S., M.O.], Institute of Laboratory Medicine [C.M.], Charité \\ Virchow University Hospital, Humboldt University Berlin, 13353 Berlin, Germany
}

\begin{abstract}
ABST
Brain-specific proteins have been used to detect cerebral
injury after birth asphyxia. Previous investigations suggest that
serum protein S-100 $\beta$, brain-specific creatine kinase $(\mathrm{CK}-\mathrm{BB})$,
and neuron-specific enolase (NSE) are capable of identifying
patients with a risk of developing hypoxic-ischemic encephalop-
athy. Whether detection of elevated serum concentrations of
these proteins reflects long-term neurodevelopmental impairment
remains to be investigated. We examined serum protein S-100 $\beta$,
NSE, and CK-BB at $2,6,12$, and 24 h after birth in 29
asphyxiated infants and 20 control infants. Neurodevelopmental
follow-up examinations were performed at 20 mo of age using
the German revision of the Griffiths scales for developmental
\end{abstract}
Perinatal asphyxia continues to be a major cause of neonatal morbidity, mortality, and neurodevelopmental disabilities (1). The early prediction of outcome is necessary to identify infants with a higher risk for brain damage for neuroprotective interventions aiming to limit the extent of brain injury (2). In an attempt to determine the cerebral injury and to predict the neurologic outcome, various investigations have been used as an adjunct to the clinical examination (3). During the last decade, biochemical indicators of brain damage have been investigated after asphyxia (4-9). A recently published study demonstrated that elevation of serum protein S-100 $\beta$ and CK-BB activity are reliable indicators of HIE after birth asphyxia (10). Protein S-100 is a dimeric acidic calcium-binding protein constituting a major component of the cytosol of various cell types. Protein S-100B ( $\beta \beta$ subunits) and S-100A1 $(\alpha \beta)$ are predominantly present in astrocytes and Schwann cells (11). NSE, a dimeric isoenzyme of the glycolytic enzyme enolase, is found in the cytoplasm of neurons and cells with

Received August 2, 2002; accepted February 4, 2003.

Correspondence: Nicole Nagdyman, Department of Neonatology, Charité Virchow University Hospital, Humboldt University Berlin, Augustenburger Platz 1, 13353 Berlin, Germany; e-mail: nicole.nagdyman@ charite.de

DOI: 10.1203/01.PDR.0000072518.98189.A0 assessment. Elevated concentrations of serum protein S-100 $\beta$, NSE, and CK-BB within $24 \mathrm{~h}$ after asphyxia did not correlate with long-term neurodevelopmental delay. We conclude that serum protein S-100 $\beta$, NSE, and CK-BB, sampled on the first day of life, is of limited value in predicting severe brain damage after birth asphyxia. (Pediatr Res 54: 270-275, 2003)
Abbreviations
HIE, hypoxic-ischemic encephalopathy
NSE, neuron-specific enolase
CK-BB, brain-specific creatine kinase (E.C. 2.7.3.2.)
DQ, developmental quotient

neuroendocrine differentiation (12). CK-BB is found in both neurons and astrocytes.

The relationship between serum CK-BB and NSE and neurodevelopmental outcome after asphyxia has been studied (47 ), but there are few data concerning measurements of these biochemical markers within $24 \mathrm{~h}$ after birth and neurodevelopmental outcome. The relationship between neurodevelopmental outcome and serum protein S-100 $\beta$ after birth asphyxia has not yet been assessed.

We examined the same population as in our previous study (10) in a neurodevelopmental follow-up study. Our objectives were to investigate whether serum protein S-100 $\beta$, NSE, and CK-BB after birth asphyxia predict long-term neurodevelopmental impairment.

\section{METHODS}

With ethics committee approval and written parental consent, we prospectively studied 29 asphyxiated patients and 20 control infants born from June 1998 to December 1999. Follow-up examinations were performed at 20 mo of age until September 2001.

Asphyxia group. Twenty-nine full-term newborn infants (gestational age, 37-42 wk) who fulfilled the following criteria were included in the study: arterial blood cord $\mathrm{pH}$ value $<7.0$, 
or arterial blood cord $\mathrm{pH}$ between 7.01 and 7.1 and also an Apgar score after 5 min of $<7$. The asphyxia group was subdivided to two groups: 1) normal outcome and 2) retardation or death.

Control group. Twenty full-term infants who fulfilled all of the following criteria were included in the control group: no maternal illness; arterial blood cord $\mathrm{pH} \geq 7.2$; after $5 \mathrm{~min}$, an Apgar score of $>7$; and an uneventful course during the first $3 \mathrm{~d}$ of life. Exclusion criteria for both groups were congenital anomalies, tumors, maternal drug addiction, severe infections, and congenital metabolic disorders. Clinical data are given in Table 1.

Study design. Blood samples were collected 2, 6, 12, and $24 \mathrm{~h}$ after birth. HIE was diagnosed according to the classification of Sarnat and Sarnat (13). Standardized neurodevelopmental examinations were performed at 20 mo of age according to the German revision of the Griffiths Developmental Scales $(14,15)$. Neurodevelopmental examiners were blinded to the category of the child and the findings at birth and in the neonatal period.

Analysis of protein S-100, NSE, and CK-BB. Protein S- $100 \beta$ was measured manually with a sandwich-type immunoluminometric assay kit (BYK Sangtec, Dietzenbach, Germany) that used MAb and a LB952 luminometer (Berthold Technologies, Bad Wildbad, Germany). The assay uses three $\mathrm{MAb}$ to detect the $\beta$ chains in the $\beta \beta$ (S-100B) and $\alpha \beta$ (S-100A1) dimers.

NSE was measured on a Cobas Core II immunoanalyzer with the NSE EIA II kit (Roche Molecular Biochemicals, Mannheim, Germany), a one-step sandwich-type enzyme immunoassay that used two specific monoclonal mouse antibodies. The manufacturers claim low detection limits of $0.02 \mu \mathrm{g} / \mathrm{L}$ for protein S-100 and $0.1 \mu \mathrm{g} / \mathrm{L}$ for NSE. Free Hb, as parameter of hemolysis, was quantified by bichromatic photometric measurement on a Hitachi 911 (Hitachi, Yokohama, Japan) or a Modular PP analyzer (Roche Molecular Biochemicals). Creatine kinase was determined at $25^{\circ} \mathrm{C}$ according to the optimized German standard method on Dax 72 (Bayer Corporation, Munich, Germany) or Modular PP (Roche Molecular Biochemicals) random assessment clinical analyzers. To quantify $\mathrm{CK}-\mathrm{BB}$, creatine kinase isoenzymes were fractionated electrophoretically on agarose gels, visualized by in-gel substrate reaction for fluorometric scanning using Helena (Greiner Biochemica, Flacht, Germany) gel kits and rapid electrophoresis system. The area under the CK-BB curve was used to calculate its concentration.

Neurodevelopmental examinations. The German revision of the Griffiths Developmental Scales, based on examinations on German infants and the first 2 y of life, was used to assess the children's development $(14,15)$. Five skill areas (locomotor, personal-social, hearing and speech, eye and hand coordination, and intellectual performance) were tested at $20 \mathrm{mo}$ of age. The general DQ was derived by relating the average subscale scores to the infants age. Mild retardation is defined as a DQ being 1-2 SD (91.8 - 97.8) below mean, severe retardation as $<2 \mathrm{SD}(<91.8)$ below mean (15). Maternal education was evaluated concerning influence on DQ. It was classified to two groups: short (no school education or $<10 \mathrm{y}$ ) and intermediate/advanced (a minimum of $10 \mathrm{y} /$ college or university entry grade). Walking unaided at $2 \mathrm{y}$ was used as additional parameter for the development of cerebral palsy according to the classification of Palisano et al. (16).

Statistical analysis. Results were expressed as median with quartiles. Group comparisons were performed with the MannWhitney $U$ test and the $\chi^{2}$ test. Positive predictive value, negative predictive value, sensitivity, specificity, and likelihood ratio of biochemical markers for neurodevelopmental retardation was assessed by receiver-operating characteristics (ROC) curve test by evaluating the optimal cutoff values. All calculations and tests were performed by means of the SPSS for Windows 7.0 (SPSS Inc., Chicago, IL, U.S.A.). A $p$ value $<0.05$ was considered to be significant.

\section{RESULTS}

Neurodevelopmental examinations were performed in 25 of 29 infants with asphyxia and all control infants. Of 29 newborns with asphyxia, seven did not develop HIE but 22 did. Fifteen newborns had mild, four moderate, and three severe HIE. One infant died within $12 \mathrm{~h}$ because of multiorgan failure, the other died at d 26 of grade 4 intraventricular hemorrhage and renal and cardiac dysfunction. Two infants were lost to follow-up examinations. The respective clinical data of the perinatal period of the two infants lost to follow-up (one developed moderate, the other mild HIE) were as follows: 5-min Apgar scores of 3 and 6, arterial cord blood $\mathrm{pH}$ of 6.90 and 6.98, base deficit of 11 in both cases, protein S-100 value of 8.7 and $2.3 \mu \mathrm{g} / \mathrm{L}$, and CK-BB activity of 48 and $8 \mathrm{U} / \mathrm{L}$ at

Table 1. Characteristics of infants with asphyxia and control infants (median/quartiles)

\begin{tabular}{|c|c|c|c|c|}
\hline \multirow[b]{2}{*}{ Characteristics } & \multirow[b]{2}{*}{$\begin{array}{c}\text { Control group, } \\
\quad n=20\end{array}$} & \multicolumn{2}{|c|}{ Infants with asphyxia } & \multirow[b]{2}{*}{$p$ Value } \\
\hline & & $\begin{array}{c}\text { Normal outcome, } n \\
=16\end{array}$ & $\begin{array}{c}\text { Retardation/death, } n \\
=11\end{array}$ & \\
\hline Birth weight (g) & $3318(2962-3886)$ & $3535(3070-3845)$ & $3155(2625-3590)$ & NS* \\
\hline Gestational age (wk) & $40(38-40)$ & $40(39-41)$ & $39(38-40)$ & NS* \\
\hline $\operatorname{Sex}(M / F)$ & $6 / 14$ & $9 / 7$ & $6 / 5$ & NS* \\
\hline Apgar score (1 min) & $8(7-9)$ & $3(1-5)$ & $4(2-7)$ & $\mathrm{NS} \dagger$ \\
\hline Apgar score (5 min) & $9(8-10)$ & $6(4-8)$ & $6(5-8)$ & $\mathrm{NS} \dagger$ \\
\hline Arterial cord blood $\mathrm{pH}$ & $7.25(7.22-7.28)$ & $6.97(6.86-7.02)$ & $6.88(6.75-6.99)$ & $\mathrm{NS} \dagger$ \\
\hline Arterial cord blood base deficit & $5(3-6)$ & $13(11-17)$ & $17(13-21)$ & $\mathrm{NS} \dagger$ \\
\hline
\end{tabular}

$* p$ Values are for comparison between control infants $(n=20)$ and infants with asphyxia $(n=27)$.

$\dagger p$ Values are for comparison between infants with normal outcome and infants with retardation or death. 
$2 \mathrm{~h}$. Birth weight, gestational age, and sex were similar among asphyxiated and control infants. Both asphyxia groups did not differ in Apgar scores at 1 and $5 \mathrm{~min}$, arterial blood cord $\mathrm{pH}$, and base deficit (Table 1).

Developmental quotient. There was no significant difference in DQ between asphyxiated and control infants. Psychomotor retardation was present in nine asphyxiated (four mild, five severe) and three control infants (two mild, one severe) without significant intergroup differences. Comparison of the five skill areas between the asphyxia and control group is given in Table 2. Developmental delay in the three control infants was particularly present in the skill area of hearing and speech, while locomotor development was normal. There was no significant difference in maternal education between asphyxiated and control infants (asphyxia group: $36 \%$ short, $64 \%$ intermediate/advanced education; control group: $37 \%$ short, $63 \%$ intermediate/advanced education). Maternal education in all three retarded control infants was classified as short.

Clinical characteristics, degree of HIE, and values of protein $\mathrm{S}-100 \beta$ and CK-BB $2 \mathrm{~h}$ after birth of the infants with psychomotor retardation and death are given in Table 3. Three infants were unable to walk unaided at $2 \mathrm{y}$ of age (Table 3). All three retarded controls did not suffer from other diseases like metabolic disorders or perinatal infections, which were ruled out by normal laboratory examinations and ultrasound examinations. Their neurologic examinations were inconspicuous.

Biochemical markers. At every time interval there was a significant difference in serum protein S-100 $\beta$ and CK-BB activities between the control and asphyxia group, but we found neither a significant difference in protein S-100 $\beta$ levels nor in serum CK-BB activities between asphyxiated infants with normal and retarded development (Table 4).

NSE levels were neither significant between control infants and the asphyxia group nor significant between both asphyxia groups (Table 4). NSE levels were increased by hemolysis, but no significant difference in hemolysis was detectable in the different groups. The predictive capacities of serum CK-BB activity, serum NSE, and cord blood base deficit for neurodevelopmental retardation are shown in Table 5. Confidence limits of predicting neurodevelopmental retardation by brainspecific proteins showed a broad distribution.

ROC curve analysis for serum protein S-100 $\beta$, Apgar scores, and arterial cord blood $\mathrm{pH}$ showed an AUC of less 0.60 and therefore we did not calculate their predictive values.

Table 2. Comparison of neurodevelopmental outcome of term infants with asphyxia $(\mathrm{n}=25)$ with term control infants $(\mathrm{n}=20)$

\begin{tabular}{lccc}
\hline Development at 20 mo & $\begin{array}{c}\text { Control group, } \\
\text { normal/retardation }\end{array}$ & $\begin{array}{c}\text { Asphyxia group, } \\
\text { normal/retardation }\end{array}$ & $\begin{array}{c}p \\
\text { Value }\end{array}$ \\
\hline Skill areas & & & \\
Locomotor & $19 / 1$ & $21 / 4$ & $\mathrm{NS}$ \\
Personal social & $16 / 4$ & $17 / 8$ & $\mathrm{NS}$ \\
Hearing and speech & $14 / 6$ & $13 / 12$ & $\mathrm{NS}$ \\
Eye-hand coordination & $16 / 4$ & $12 / 13$ & 0.027 \\
Intellectual performance & $17 / 3$ & $12 / 13$ & 0.01 \\
\hline
\end{tabular}

\section{DISCUSSION}

As expected, we detected more infants with neurodevelopmental retardation in the asphyxia group than in the control group, but the difference failed to be significant, which might be due to the small proportion of retarded cases. Our hospital serves as a referral center for high-risk pregnancies, with delivery numbers of 3500-3700 per year. During the 18-mo study period, there were 29 asphyxiated infants meeting the strict entry criteria, most of whom developed no or only mild HIE. This low number is not restricted to our hospital but rather reflects a global trend $(17,18)$ : the incidence of asphyxia has steadily declined in most developed countries to such a degree that severe asphyxia now qualifies for orphan disease status. This success of modern perinatal care may have complex roots, and it poses an enormous obstacle to researchers in the field. However, we feel that it is important to also report on low numbers, rather than not to report on asphyxiated infants at all.

We observed a high incidence of psychomotor retardation in the control group. With regard to exclusion of metabolic disorders and congenital anomalies, a possible explanation might be low maternal education as an influencing factor for the delay in neurodevelopment. Our study group had a higher portion of short maternal education compared with a former study in Berlin, where preconceptional factors associated with low birthweight deliveries were analyzed (19). We know that maternal education positively relates to children's intelligence quotient (20) and the retardation of the three infants particular in the skill area of hearing and speech might be due to this socioeconomic factor.

Cord blood $\mathrm{pH}$, arterial cord blood deficit, and Apgar scores were not predictive for neurodevelopmental retardation after birth asphyxia in our study population. There is an ongoing discussion on prediction of asphyxial sequelae. Fetal heart rate patterns, need of resuscitation, umbilical arterial blood gas analysis, and Apgar scores showed variable predictive values (21-25), most likely due to the nonhomogeneity of the studied populations. Toh (23) reported a positive predictive value of $100 \%$ for either death or major neurologic disability using a combination of a 5-min Apgar score $<4$ and arterial blood base deficit of more than $20 \mathrm{mM}$ within $2 \mathrm{~h}$ after birth. Unlike our study, this study selected only infants with moderate and severe HIE. Presence of moderate or severe HIE has a high sensitivity (96\%) in predicting death or severe handicap compared with Apgar scores (21). In our study population, all infants with severe HIE and half of the infants with moderate HIE suffered from retardation. As the HIE staging is performed at $24 \mathrm{~h}$ (13), its value in selecting infants for intervention is low.

In a previous study we demonstrated that a combination of serum protein $\mathrm{S}-100 \beta$ (cutoff value, $8.5 \mu \mathrm{g} / \mathrm{L}$ ) and CK-BB activity (cutoff value, $18.8 \mathrm{U} / \mathrm{L}$ ) $2 \mathrm{~h}$ after birth had the highest positive predictive value (83\%) and specificity (95\%) for moderate and severe HIE (10). However, until now, no study has examined the predictive value of serum protein $\mathrm{S}-100 \beta$ for neurodevelopmental retardation after asphyxia. Maschmann et al. (26) discussed elevated protein $\mathrm{S}-100 \beta$ values as a marker 
Table 3. Clinical data of infants with psychomotor retardation and death and biochemical parameters

\begin{tabular}{|c|c|c|c|c|c|c|c|c|c|}
\hline $\begin{array}{l}\text { Patient } \\
\text { no. }\end{array}$ & Sex & $\begin{array}{c}\text { Arterial cord } \\
\text { blood } \mathrm{pH}\end{array}$ & $\begin{array}{c}\text { Apgar score } \\
5 \mathrm{~min}\end{array}$ & $\begin{array}{l}\text { Base deficit } \\
\mathrm{mmol} / \mathrm{L}\end{array}$ & $\begin{array}{c}\mathrm{S}-100 \beta \mu \mathrm{g} / \mathrm{L} \\
(2 \mathrm{~h})\end{array}$ & $\begin{array}{c}\text { CK-BB U/L } \\
(2 \mathrm{~h})\end{array}$ & HIE/death & DQ & $\begin{array}{c}\text { Walking unaided } \\
\text { at } 2 \mathrm{y}\end{array}$ \\
\hline 1 & $M$ & 6.75 & 1 & 30 & 50.7 & 83 & Death & Dead & - \\
\hline 2 & M & 6.73 & 5 & 22 & 31.9 & 45 & 3/death & Dead & - \\
\hline 4 & F & 6.88 & 5 & 15 & 2.4 & 19 & 3 & 40 & No \\
\hline 5 & F & 6.98 & 3 & 17 & 3.2 & 19 & 2 & 77 & No \\
\hline 6 & $\mathrm{M}$ & 6.98 & 9 & 11 & 1.6 & 15 & 1 & 78 & Yes \\
\hline 9 & M & 6.99 & 8 & 15 & 1.2 & 38 & 2 & 95 & Yes \\
\hline 10 & M & 7.01 & 6 & 13 & 5.3 & 13 & 1 & 95 & Yes \\
\hline 11 & $\mathrm{~F}$ & 6.85 & 9 & 20 & 1.7 & 15 & 0 & 96 & Yes \\
\hline 12 & M & 7.25 & 7 & 8 & 1.2 & 9 & 0 & 86 & Yes \\
\hline 13 & $\mathrm{M}$ & 7.28 & 10 & 4 & 1.8 & 10 & 0 & 94 & Yes \\
\hline 14 & $\mathrm{~F}$ & 7.25 & 8 & 5 & 1.3 & 5 & 0 & 96 & Yes \\
\hline
\end{tabular}

DQ, psychomotor developmental quotient (severe retardation <91.8, mild retardation 91.8-97.8); HIE, hypoxic-ischemic encephalopathy.

Patients 1-11: asphyxia group; patients 12-14: control infants.

Table 4. Serial measurements of serum protein-S100 $\beta, N S E$, and CK-BB after birth asphyxia

\begin{tabular}{|c|c|c|c|c|c|}
\hline $\begin{array}{l}\text { Biochemical markers } \\
\text { (median/quartiles) }\end{array}$ & Control group & \multicolumn{2}{|c|}{ Infants with asphyxia } & $p$ Value* & $p$ Value\# \\
\hline at $2 \mathrm{~h}$ & $1.6(1.4-2.5)$ & $3.3(2.2-8.4)$ & $3.6(1.7-17)$ & $<0.0001$ & NS \\
\hline at $6 \mathrm{~h}$ & $1.6(1.2-2.3)$ & $2.5(1.5-4.6)$ & $3.8(1.9-27.6)$ & 0.001 & NS \\
\hline at $12 \mathrm{~h}$ & $1.2(1.1-1.5)$ & $1.8(1.5-2.9)$ & $1.6(1.3-2.4)$ & 0.001 & NS \\
\hline at $2 \mathrm{~h}$ & $30.3(24.8-47.6)$ & $32.5(19.9-53.8)$ & $55.1(32.5-89.0)$ & NS & NS \\
\hline at $6 \mathrm{~h}$ & $37.1(19.0-48.8)$ & $36.7(30.1-54.9)$ & 48.7 (33.7-95.8) & NS & NS \\
\hline at $12 \mathrm{~h}$ & $28.7(19.8-39.4)$ & $38.5(24.3-48.8)$ & $47.8(30.1-64.9)$ & NS & NS \\
\hline at $24 \mathrm{~h}$ & $24.3(17.2-39.5)$ & $36.3(17.6-51.8)$ & $39.1(34.0-55.4)$ & NS & NS \\
\hline \multicolumn{6}{|l|}{ CK-BB (U/L) } \\
\hline at $2 \mathrm{~h}$ & $10.0(6.0-13.0)$ & $17.5(13.0-22.0)$ & $22.7(15.0-38.3)$ & $<0.0001$ & NS \\
\hline
\end{tabular}

* $p$ Values are for comparison between all asphyxiated infants and controls. \# $p$ Values are for comparison between asphyxiated infants with normal outcome and infants with retardation or death.

Table 5. Values for predicting neurodevelopmental retardation after asphyxia

\begin{tabular}{lcccccccc}
\hline \multicolumn{1}{c}{ Parameter } & Cut-off value & $\begin{array}{c}\text { PPV } \\
(\%)\end{array}$ & $\begin{array}{c}\text { NPV } \\
(\%)\end{array}$ & $\begin{array}{c}\text { Sens } \\
(\%)\end{array}$ & $\begin{array}{c}\text { Spec } \\
(\%)\end{array}$ & $\begin{array}{c}\text { Likelihood } \\
\text { ratio }\end{array}$ & AUC & $95 \%$ Confidence limits \\
\hline CK-BB & & & & & & & & \\
$\quad$ at $2 \mathrm{~h}$ & $19 \mathrm{U} / \mathrm{L}$ & 60 & 71 & 71 & 60 & 1.77 & 0.654 & $0.438-0.879$ \\
$\quad$ at $6 \mathrm{~h}$ & $12.5 \mathrm{U} / \mathrm{L}$ & 53 & 75 & 73 & 56 & 1.58 & 0.665 & $0.455-0.875$ \\
NSE & & & & & & & \\
at 2 h & $44 \mu \mathrm{g} / \mathrm{L}$ & 60 & 69 & 60 & 69 & 1.93 & 0.712 & $0.493-0.930$ \\
$\quad$ at $6 \mathrm{~h}$ & $43 \mu \mathrm{g} / \mathrm{L}$ & 54 & 77 & 67 & 67 & 2.0 & 0.674 & $0.446-0.902$ \\
Cord blood base deficit & $>14 \mathrm{mmol} / \mathrm{L}$ & 53 & 75 & 73 & 56 & 1.65 & 0.679 & $0.467-0.891$ \\
\hline
\end{tabular}

PPV, positive predictive value; NPV, negative predicting value; Sens, sensitivity; Spec, specifity; likelihood ratio = sens/1 - specificity; AUC, area under the curve. Calculation for protein $\mathrm{S}-100 \beta$ was not performed, AUC was $<0.60$.

of central nervous damage after birth asphyxia, serum sampling was random, and the neurologic survey not standardized. In cerebrospinal fluid, brain-specific proteins correlated well with long-term prognosis, especially with death, as in our study, but infants with and without neurological handicaps did not have significantly different values (27). Our results did not show a strong relationship between the serum protein $S-100 \beta$ concentration within $24 \mathrm{~h}$ after asphyxia and neurodevelop- mental outcome, although both infants who died from asphyxia had extremely high serum protein S- $100 \beta$ levels. Reliable prognostic markers must have higher specificity and positive predictive values. They are clinically relevant if they help to discriminate between infants with normal outcome and those with psychomotor retardation (28). Protein S- $100 \beta$ release after birth asphyxia resembles the transient increase after cardiac operations, which also did not correlate with cerebral 
outcome (29). In adults with acute ischemic stroke, serum protein $\mathrm{S}-100 \beta$ peaks $3 \mathrm{~d}$ after onset of symptoms (30). In asphyxiated newborns, serum protein S-100 $\beta$ peaked within 2-6 $\mathrm{h}$ after birth, presumably due to transitory increased permeability of the blood-brain barrier and decreased renal excretion as part of the asphyxial event (10). An experimental study demonstrated an early increase in the synthesis of intermediary filaments after hypoxic-ischemic events (31). After severe hypoxic-ischemic insult, cell death and disruption of cell membranes might increase the extracellular concentrations, which could further be transferred to the cerebrospinal fluid and explains the correlation to high concentrations of protein S-100 $\beta$ in the cerebrospinal fluid (27). Differing bloodbrain barriers may explain why serum concentration in newborns is higher than in adults (30). Another possible mechanism might be the neurotrophic role possibly exerted by protein S-100 $\beta$. Gazzolo et al. (32) detected higher concentrations of serum protein $\mathrm{S}-100 \beta$ in preterm infants compared with term infants, which might be due to higher concentrations of the trophic factor at earlier gestational ages. Brain damage does not necessarily result in a blood-brain rupture and protein $\mathrm{S}-100 \beta$ is not released exclusively from the brain, but also present in striated muscle, heart, kidneys, adipocytes, and thymus of newborns (12). As demonstrated in our former study (10), serum protein S-100 $\beta$ should be regarded as a marker for acute impairment like HIE.

Serum NSE measurements did not supply reliable information about neurodevelopmental impairment after birth asphyxia and even did not distinguish between infants with asphyxia from control infants. A recently published study (33) regards elevated serum NSE values as a sensitive indicator of brain damage, and other studies found NSE in cerebrospinal fluid a more accurate marker of motor impairment after asphyxia (7, 27, 34).

Our results demonstrate that elevated serum CK-BB activity it is of limited value to predict the long-term neurodevelopmental outcome after birth asphyxia. Our serum CK-BB activities were lower than in the former studies (4-6), a possible explanation for which might be the measurement of total creatine kinase activity at different temperatures. Also, CK-BB might arise from noncerebral sources, as it is also expressed in placenta, gastrointestinal tract, kidneys, and lungs (35). Cuestas (36) demonstrated that the CK-BB levels are not elevated in neonates with renal or gastrointestinal disorders. Studies differ concerning their assessment as a predictive marker for adverse outcome after asphyxia. Some studies have demonstrated a correlation between elevated CK-BB activity at 6-12 h of life and neurologic outcome (4), whereas others have found a weak correlation to neurologic sequelae at $4 \mathrm{~h}$ after birth (6). A large retrospective study could not demonstrate a significant correlation between elevated CK-BB activity and adverse neurologic outcome (5).

The predictive value on outcome of amplitude-integrated EEG has been published to be $91.5 \%$ (37). Taking into consideration that our data are from a small number of retarded infants, we conclude that serum protein S-100 $\beta$, NSE, and CK-BB, sampled on the first day of life, are of limited value in predicting severe brain damage after birth asphyxia.

\section{REFERENCES}

1. Goodwin TM, Belai I, Hernandez P, Durand M, Paul RH 1992 Asphyxial complications in the term newborn with severe umbilical acidemia. Am J Obstet Gynecol 162:1506-1512

2. Levene MI, Evans DJ, Mason S, Brown J 1999 An international network for evaluating neuroprotective therapy after severe birth asphyxia. Semin Perinatol 23:226-233

3. Groenendaal F, de Vries LS 2000 Selection of babies for intervention after birth asphyxia. Semin Neonatol 5:17-32

4. Walsh P, Jedeikin R, Ellis G, Primhak R, Maleka SK 1982 Assessment of neurologic outcome in asphyxiated term infants by use of serial CK-BB isoenzyme measurement. J Pediatr 101:988-992

5. Sweet DG, Bell AH, McClure G, Wallace IJ, Shields MD 1999 Comparison between creatine kinase brain isoenzyme (CKBB) activity and Sarnat score for prediction of adverse outcome following perinatal asphyxia. J Perinat Med 27:478-483

6. Fernandez F, Verdu A, Quero J, Perez-Higueras A 1987 Serum CKP-BB isoenzyme in the assessment of brain damage in asphyxiated term infants. Acta Pediatr Scand 76:914-918

7. Garcia-Alix A, Cabanas F, Pellicer A, Hernanz A, Stiris TA, Quero J 1994 Neuronspecific enolase and myelin basic protein: relationship of cerebrospinal fluid concentrations to the neurologic condition of asphyxiated full-term infants. Pediatrics 93:234-240

8. Blennow M, Hagberg H, Rosengren L 1995 Glial fibrillary acidic protein in the cerebrospinal fluid: a possible indicator of prognosis in full-term asphyxiated newborn infants? Pediatr Res 37:260-264

9. Hagberg H, Thornberg E, Blennow M, Kjellmer I, Lagercrantz H, Thiringer K, Hamberger A, Sandberg M 1993 Excitatory amino acids in the cerebrospinal fluid of asphyxiated infants: relationship to hypoxic-ischemic encephalopathy. Acta Paediatr 82:925-929

10. Nagdyman N, Kömen W, Ko HK, Müller C, Obladen M 2001 Early biochemical indicators of hypoxic-ischemic encephalopathy after birth asphyxia. Pediatr Res 49:502-506

11. Kligman D, Hilt DC 1998 The protein S 100 family. Trends Biochem Sci 11:437-443

12. Haimoto H, Hosoda S, Kato K 1987 Differential distribution of immunoreactive S100-alpha and S100-beta proteins in normal nonnervous human tissues. Lab Invest 57:489-498

13. Sarnat HB, Sarnat MS 1976 Neonatal encephalopathy following fetal distress: a clinical and electroencephalographic study. Arch Neurol 33:696-705

14. Griffiths R 1970 Abilities of Young Children: A Comprehensive System of Mental Measurement for the First Eight Years of Life. Chard, Somerset, Young and Son, London, pp 34-35

15. Brandt I 1983 Griffiths Entwicklungsskalen (GES) zur beurteilung der entwicklung in den ersten beiden lebensjahren. Beltz, Weinheim, Basel, pp 76-166

16. Palisano R, Rosenbaum P, Walter S, Russell D, Wood E, Galuppi B 1997 Development and reliability of a system to classify gross motor function in children with cerebral palsy. Dev Med Child Neurol 39:214-223

17. Thornberg E, Thiringer K, Odeback A, Milsom I 1995 Birth asphyxia: incidence, clinical course and outcome in a Swedish population. Acta Paediatr 84:927-932

18. Smith J, Wells L, Dodd K 2000 The continuing fall in incidence of hypoxic-ischaemic encephalopathy in term infants. BJOG 107:461-466

19. Grimmer I, Bührer C, Dudenhausen JW, Stroux A, Reiher H, Halle H, Obladen M 2002 Preconceptional factors associated with very low birthweight delivery in East and West Berlin: a case control study. BMC Public Health 2:10-17

20. Breslau N, Chilcoat HD, Susser ES, Matte T, Liang KY, Peterson EL 2001 Stability and change in children's intelligence scores: a comparison of two socioeconomically disparate communities. Am J Epidemiol 154:711-717

21. Levene MI, Sands C, Grindulis H, Moore JR 1986 Comparison of two methods of predicting outcome in perinatal asphyxia. Lancet 1:67-69

22. Ruth VJ, Raivo KO 1988 Perinatal brain damage: predictive value of metabolic acidosis and Apgar score. BMJ 297:24-27

23. Toh VC 2000 Early predictors of adverse outcome interm infants with post-asphyxial ischemic encephalopathy. Acta Paediatr 89:343-347

24. Asakura H, Ichikawa H, Nakabayashi M, Ando K, Kaneko K, Kawabata M, Tani A, Satoh M, Takahashi K, Sakamoto S 2000 Perinatal risk factors related to neurolgic outcomes of term newborns with asphyxia at birth: a prospective study. J Obstet Gynaecol Res 26:313-324

25. Socol ML, Garcia PM, Riter S 1994 Depressed Apgar scores, acid-base status, and neurologic outcome. Am J Obstet Gynecol 170:991-999

26. Maschmann J, Erb, Heinemann MK, Ziemer G, Speer CP 2000 Evaluation of protein S-100 serum concentrations in healthy newborns and seven newborns with perinatal acidosis. Acta Paediatr 89:553-555

27. Blennow M, Sävman K, Ilves P, Thoresen M, Rosengren L 2001 Brain-specific proteins in the cerebrospinal fluid of severely asphyxiated infants. Acta Paediatr 90:1171-1175

28. Garcia-Alix A, Quero J 2001 Brain-specific proteins as predictors of outcome in asphyxiated term infants. Acta Paediatr 90:1103-1105

29. Westaby S, Saatvedt K, White S, Katsumata T, Oeveren W, Bhatnagar NK, Brown S, Halligan PW 2000 Is there a relationship between serum S-100 $\beta$ protein and neuropsychologic dysfunction after cardiopulmonary bypass. J Thorac Cardiovasc Surg 119:132-137

30. Missler U, Wiesmann M, Friedrich C, Kaps M 1997 S-100 protein and neuronspecific enolase concentrations in blood as indicators of infarction volume and prognosis in acute ischemic stroke. Stroke 28:1956-1960

31. Rischke R, Kriegelstein J 1991 Postischemic neuronal damage causes astroglial activation and increase in local cerebral glucose utilization of rat hippocampus. J Cereb Blood Flow Metab 11:106-113 
32. Gazzolo D, Vinesi P, Marinoni E, Di Iorio R, Marras M, Lituania M, Bruschettini P, Michetti F 2000 S100B protein concentrations in cord blood: correlations with gestational age in term and preterm deliveries. Clin Chem 46:998-1000

33. Verdu Perez A, Falero MP, Arroyos A, Estevez F, Felix V, Lopez Y, Pantoja A, Ureta A 2001 Blood neuronal specific enolase in newborns with perinatal asphyxia. Rev Neurol 32:714-717

34. Thornberg E, Thiringer K, Hagberg H, Kjellmer I 1995 Neuron specific enolase in asphyxiated newborns: association with encephalopathy and cerebral function mon- itor trace. Arch Dis Child Fetal Neonatol Ed 72:F39-F42

35. Laboda HM, Britton VJ 1977 Creatine kinase isoenzyme activity in human placenta and in serum of women in labour. Clin Chem 23:1329-1335

36. Cuestas Jr RA 1980 Creatine kinase isoenzymes in high risk infants. Pediatr Res 14:935-938

37. Hellström-Westas L, Rosén I, Svenningsen NW 1995 Predictive value of early continuous amplitude integrated EEG recordings on outcome after severe birth asphyxia in full term infants. Arch Dis Child 72:F34-F38 